\title{
The expression of atrial natriuretic peptide in the oviduct and its functions in pig spermatozoa
}

\author{
Meijia Zhang, Haiyan Hong, Bo Zhou, Shiying Jin, Chao Wang, \\ Maoyong Fu, Songbo Wang and Guoliang Xia
}

Department of Animal Physiology and Biochemistry, College of Biological Sciences, China Agricultural University, Beijing 100094, People's Republic of China

(Requests for offprints should be addressed to G Xia; Email: glxiachina@sohu.com)

\begin{abstract}
Locally synthesized atrial natriuretic peptide (ANP) and its receptors have been found in reproductive tissues of various mammals, and play an important role in the acrosome reaction of human sperm. The objective of the present study was to examine the expression of ANP and its receptors in pig spermatozoa and oviduct, and the effect of ANP on pig spermatozoa function. The expression of ANP and its receptors was analyzed by RT-PCR. Only natriuretic peptide receptors-A (NPRA) mRNA was detected in fresh sperm. While the levels of natriuretic peptide receptors-C (NPRC) mRNA were low with no obvious change among different oviductal phases, the levels of ANP mRNA were high in oviduct(OT)1, OT3 and OT5, but were very low in OT2. On the other hand, the levels of NPRA mRNA were low in OT1 and OT2, increased in OT3 and reached a maximum in OT4 and OT5. Western blot analysis revealed that the level of ANP was high in OT1, decreased in OT2 and OT3, and arrived at the nadir in OT4 and OT5. The effect of ANP on spermatozoa function was studied by the acrosome reaction and IVF. Incubation with ANP for $1 \mathrm{~h}$
\end{abstract}

significantly induced acrosome reaction of preincubated spermatozoa, and maximal response of acrosome reaction $(34 \cdot 1 \pm 2 \cdot 3 \%)$ was achieved at $1 \mathrm{nM}$ ANP treatment. Both C-ANP-(4-23), a selective ligand of NPRC, and caffeine had no effect on the acrosome reaction. The stimulatory effect of ANP on acrosome reaction could be mimicked by the permeable cGMP analog, 8-Br-cGMP. ANP and caffeine had a similar effect on improving the oocytes penetration rate, polyspermy rate and the average number of sperm per penetrated oocyte. Also, ANP treatment had a similar effect on cleavage rate, blastocyst formation rate and the number of cells per blastocyst as that of caffeine treatment. The effects of ANP on the acrosome reaction and the parameters of oocyte penetration could be blocked by cGMP-dependent protein kinase (PKG) inhibitors KT5823 and/or Rp-8-pCPT-cGMPS. These results suggest that the expression of ANP in the oviduct may be involved in the regulation of the acrosome reaction and the fertilising ability of pig spermatozoa, and the PKG pathway possibly participates in the process.

Journal of Endocrinology (2006) 189, 493-507

\section{Introduction}

Atrial natriuretic peptide (ANP) or atrial natriuretic factor (ANF) is a member of a family of peptides that share a common 17 -amino acid ring closed by a disulfide bond between two cysteine residues and varying only in length of their N- and C-terminal extensions (Flynn et al. 1983). ANP is mainly involved in the regulation of blood pressure, salt and water excretion, cell proliferation and body fluid homeostasis (Ruskoaho 1992). In addition, extra-atrial sites that synthesize ANP have been found in discrete areas, including the hypothalamus, pituitary gland, adrenal medulla, gastrointestinal tract and thymus (Gutkowska \& Nemer 1989). ANP and its receptors have been found in the corpus luteum (Vollmar et al. 1988), ovary and follicular fluid (Anderson et al. 1994), granulosa cells (Kim et al. 1992, Ivanova et al. 2003), oocytes
(Kim et al. 1993), oviduct (Kim et al. 1997), testis (Pelletier 1988), and spermatozoa (Silvestroni et al. 1992). Such findings suggest that the locally synthesized ANP may act in an autocrine or paracrine fashion in certain tissues to produce physiological responses (Tornell et al. 1990, Anderson et al. 1994, Johnson et al. 1994, Zamir et al. 1995, Evrard et al. 1999). The diverse physiological actions of ANP are manifested by binding to its specific cell-surface receptors (for review, see Takei 2001). ANP exhibits high affinity to natriuretic peptide receptors-A (NPRA) and natriuretic peptide receptors-C (NPRC; for review, see Takei 2000). NPRA receptors can activate particulate guanylate cyclase and stimulate cGMP to produce physiological response in many tissues and cells (Pandey et al. 2000), while NPRC receptors have no intrinsic ability to generate cGMP (Drewett et al. 1992). 
In mammals, sperm are not immediately capable of fertilising oocytes. They must undergo modifications that normally occur in the female reproductive tract (Austin 1951, Chang 1951). The changes that occur in sperm involve at least two components: capacitation (Yanagimachi 1981) and acrosome reaction (Yanagimachi \& Usui 1974). Yet, the in vivo factors that capacitate sperm and induce the acrosome reaction are unknown in most species. Caffeine and heparin have been widely used as suitable alternatives to improve the success rate of IVF (Parrish et al. 1986, Niwa \& Ohgoda 1988, Yoshida et al. 1990). It has been reported that ANP is synthesized in the mucosal layer of rat oviduct, but its local role is not very clear (Kim et al. 1997). ANP induces spermatozoa chemokinesis and chemotaxis (Zamir et al. 1993, Anderson et al. 1995), which may be beneficial for the spermatozoa to resume high motility and travel the distance between the storage site and the fertilisation site at the oviductal ampulla (Hunter 1993). In addition, some studies provide evidence that ANP induces an acrosome reaction in both human (Anderson et al. 1994, Rotem et al. 1998) and bovine spermatozoa (Zamir et al. 1995), and concentrations of ANP in human follicular fluids are correlated with successful IVF (Anderson et al. 1994). Therefore, locally produced ANP may play an important role in mammalian sperm function. Although some agonists (such as caffeine and heparin) are widely used for spermatozoa capacitation and IVF in domestic animals (Parrish et al. 1986, Niwa \& Ohgoda 1988, Abeydeera \& Day 1997b, Zhao et al. 2002), the mechanisms of fertilisation in vivo are unclear. In the present study, we analyzed ANP and natriuretic peptide receptors gene expression in pig sperm and oviduct. In addition, the effects of ANP on the acrosome reaction and the fertilising ability of pig spermatozoa were also examined.

\section{Materials and Methods}

\section{Chemicals and media}

The synthetic human ANP-(1-28), \{des $\left(\mathrm{Gln}^{18} \mathrm{Ser}^{19}\right.$ Gly $^{20} \mathrm{Leu}^{21} \mathrm{Gly}^{22}$ ) rANF-(4-23)-NH $\}$ \{C-ANP-(4-23) $\}$, anti-ANP, anti- $\beta$-actin, 8-Br-cGMP, caffeine, KT5823, Rp-8-pCPT-cGMPS, H89, lysophosphatidylcboline, bovine serum albumin (BSA), insulin, epidermal growth factor (EGF), human chorionic gonadotrophin (hCG), porcine follicle-stimulating hormone (FSH), bismark brown, rose bengal and trypan blue were purchased from Sigma Chemical Company. The ANP, C-ANP-(4-23), 8-Br-cGMP, Rp-8-pCPT-cGMPS, H89 and lysophosphatidylcboline were prepared as $0.1 \mathrm{mM}, 0.1 \mathrm{mM}, 0.5 \mathrm{M}$, $50 \mu \mathrm{M}, 5 \mu \mathrm{M}$ and $10 \mathrm{mg} / \mathrm{ml}$ stock solutions in distilled deionized $\mathrm{H}_{2} \mathrm{O}$ (dd $\mathrm{H}_{2} \mathrm{O}$ ), respectively, and KT5823 as $1 \mathrm{mM}$ stock solution in ethyl acetate. These stock solutions were kept at $-20{ }^{\circ} \mathrm{C}$ and added at the beginning of culture. Human ANP was used in our study, since the whole hormone sequences of ANP are conserved within mammals (for review, see Takei 2001).

The basic medium used for in vitro oocyte maturation (IVM) was NCSU-37 solution (Funahashi et al. 1994) containing $10 \%$ porcine follicular fluid $(\mathrm{v} / \mathrm{v}), 1 \cdot 0 \mathrm{mM}$ glutamine, $0.6 \mathrm{mM}$ L-cysteine, $100 \mathrm{IU} / \mathrm{ml}$ penicillin $\mathrm{G}$ potassium (Sigma), $50 \mu \mathrm{g} / \mathrm{ml}$ streptomycin sulfate (Sigma), $5 \mu \mathrm{g} / \mathrm{ml}$ insulin, $10 \mathrm{ng} / \mathrm{ml} \mathrm{EGF}, 10 \mathrm{IU} / \mathrm{ml} \mathrm{hCG}$ and $0 \cdot 05$ $\mathrm{U} / \mathrm{ml}$ FSH. Basic IVF medium, designated modified Tris-buffered medium (mTBM), was as described by Abeydeera \& Day (1997a). The complete IVF medium contained $0.5 \%$ BSA, $2 \mathrm{mM}$ caffeine, $1 \mathrm{nM}$ ANP and/or $1 \mu \mathrm{M}$ KT5823. Culture medium for embryo development was North Carolina State University (NCSU) 23 (Petters \& Wells 1993 ) containing $0 \cdot 4 \% \mathrm{BSA}, 75 \mu \mathrm{g} / \mathrm{ml}$ potassium penicillin $\mathrm{G}$ and $50 \mu \mathrm{g} / \mathrm{ml}$ streptomycin sulfate.

\section{RNA isolation and RT-PCR}

Fresh semen was collected from fertile boars by the gloved hand method (King \& Macpherson 1973), and then washed with the Percoll (Sigma) technique (Parrish et al. 1995). Briefly, isotonic Percoll solution was used for preparation of $90 \%$ and $45 \%$ gradients with phosphatebuffered saline (PBS) medium. The Percoll density gradient was made by layering $2.5 \mathrm{ml}$ of $45 \%$ Percoll solution on the $2.5 \mathrm{ml}$ of $90 \%$ solution in $15 \mathrm{ml}$ Falcon tubes. On the top of the gradient $1 \mathrm{ml}$ of fresh semen was layered and then tubes were centrifugated for $10 \mathrm{~min}$ at $700 \boldsymbol{g}$, and the pellets were then washed with PBS for three times $(500 \mathrm{~g}$ for $10 \mathrm{~min}$ ). Pig oviducts connected to the ovary were collected from a local slaughterhouse and transported to the laboratory within $2 \mathrm{~h}$ at $4{ }^{\circ} \mathrm{C}$. Total RNA was extracted from Percoll-washed spermatozoa and oviduct using TRI reagent (Sigma) according to the instructions of the manufacturer, and dissolved in $20 \mu \mathrm{l}$ nuclease-free water. According to the follicular characterization of the ovary, five oviductal phases throughout the estrous cycle were defined as follows (Fig. 1A): (1) Oviduct at the small follicle stage (the diameter of all follicles in the ovary was less than $3 \mathrm{~mm}$, OT1); (2) oviduct at the middle follicle stage (a few of $3-6 \mathrm{~mm}$ follicles existed in the ovary, OT2); (3) oviduct at the large follicle stage (a few of more than $6 \mathrm{~mm}$ follicles existed in the ovary, OT3); (4) oviduct at the corpus rubrum stage (OT4); (5) oviduct at the corpus luteum stage (OT5). Semi-quantitative RT-PCR was performed as described by Piao et al. (2004). Briefly, $1 \mu \mathrm{g}$ total RNA was reverse transcribed at $42^{\circ} \mathrm{C}$ for $50 \mathrm{~min}$, denatured at $95^{\circ} \mathrm{C}$ for $2 \mathrm{~min}$, and amplified for 32 (beta-actin) or 35 (ANP, NPRA and NPRC) cycles of denaturation at $94{ }^{\circ} \mathrm{C}$ of $30 \mathrm{~s}$, primer annealing at $54{ }^{\circ} \mathrm{C}$ for $30 \mathrm{~s}$, and extension at $72{ }^{\circ} \mathrm{C}$ for $30 \mathrm{~s}$, with a final extension step of $5 \mathrm{~min}$ at $72{ }^{\circ} \mathrm{C}$. The amplified products were analyzed by electrophoresis on $1 \%$ agarose gels. Oligonucleotide primer used for amplification of the ANP was from known cDNA sequence of porcine ANP 
Table 1 Primers used for determinations of pig ANP mRNA, NPRA mRNA and NPRC mRNA by RT-PCR

\begin{tabular}{|c|c|c|c|}
\hline & Primer sequence & $\begin{array}{l}\text { Predicted } \\
\text { product size }(b p)\end{array}$ & Amplification \\
\hline \multicolumn{4}{|l|}{ mRNA } \\
\hline \multirow[t]{2}{*}{ ANP } & F: 5'-ACGACGCCAGCATGAGCTCCTTC-3' (1-23) & 474 & 35 \\
\hline & R: 5'-GCTGTTATCTTCAGTACCGGAA-3' (453-474) & & \\
\hline \multirow[t]{2}{*}{ NPRA } & F: 5'-GAGCCCAGTAGCCTTGAGA-3' (2016-2034) & 460 & 35 \\
\hline & R: 5'-CTACCACGCAGTTGGATGAC-3' (2456-2475) & & \\
\hline \multirow[t]{2}{*}{ NPRC } & F: 5'-GGGCAGTGAGCGAGTGGT-3' (757-774) & 401 & 35 \\
\hline & R: 5'-CСССАТССТTCTTGСТGT-3' (1140-1157) & & \\
\hline \multirow[t]{2}{*}{ beta-actin } & F: 5'-TCCAGCCTTCCTTCTTGGGTAT-3' (865-886) & 557 & 32 \\
\hline & R: 5'-CGCCTTCACCGTTCCAGTTT-3' (1402-1421) & & \\
\hline
\end{tabular}

$F$, forward; R, reverse.

(GenBank accession no. X54669). This primer pair predicts 474-basepair (bp) DNA fragments (Mä gert et al. 1990). The primer used for amplification of the NPRA was from known cDNA sequences of human NPRA (GenBank accession no. NM000906). The upstream primer has identical nucleotides 2016-2034 of human cDNA, and the downstream primer represents the reverse complement of nucleotides 2456-2475 (Table 1). This primer pair predicts 460-bp DNA fragments. The primer used for amplification of the NPRC was from known cDNA sequence of rat NPRC (GenBank accession no. NM012868). This primer pair predicts 401-bp DNA fragments (Piao et al. 2004). The beta-actin primers were based on the mouse sequence (GenBank accession no. NM007393).

\section{Western blot analysis}

Partially purified proteins $(15 \mu \mathrm{g})$ from pig sperm and oviduct were separated on 15\% SDS-PAGE and transferred onto nitrocellulose membranes (Bio-Rad) by the methods of Fan et al. (2003). Non-specific binding was blocked by overnight incubation of membrane in $5 \%$ nonfat dry milk in PBS containing 0.1\% tween-20 (PBST, $\mathrm{pH} 7 \cdot 5)$. Membranes were incubated with 1:200 goat anti-ANP antibody (Sigma) for $2 \mathrm{~h}$ and then washed three times (10 min each wash) with PBST. The membrane was incubated for $1 \mathrm{~h}$ at $37^{\circ} \mathrm{C}$ with horseradish peroxidase (HRP)-conjugated rabbit anti-goat immunoglobulin G ( $\operatorname{IgG}$ ) diluted 1:1000 in PBST. Proteins on the membrane were visualized using the enhanced chemiluminescence detection system (Amersham). The levels of $\beta$-actin were detected at the same time.

\section{Preparation of spermatozoa and acrosomal reaction evaluation}

Fresh sperm cells were washed twice $(500 \boldsymbol{g}$ for $10 \mathrm{~min}$ ) with $\mathrm{MTBM}$ medium containing $0.5 \%$ of bovine serum albumin (BSA) and incubated at a temperature of $37^{\circ} \mathrm{C}$ in a humidified $5 \% \mathrm{CO}_{2}$ atmosphere for $2 \cdot 5 \mathrm{~h}$. All centrifugations were performed in covered tubes. Sperm cells $\left(1 \times 10^{8}\right.$ cells/aliquot with the volume of $\left.1 \mathrm{ml}\right)$ were then incubated with the various hormones and/or drugs for further $60 \mathrm{~min}$ at $37^{\circ} \mathrm{C}$. Acrosomal sperm status was analyzed by the triple-stain technique, as described by Talbot \& Chacon (1981) and Rotem et al. (1998). Briefly, sperm were resuspended in PBS without BSA, stained with trypan blue for $15 \mathrm{~min}$, fixed in paraformaldehyde (4\% in PBS) for $30 \mathrm{~min}$ at room temperature and then washed twice $(500 \mathrm{~g}$ for $10 \mathrm{~min}$ ) with double distilled (dd) $\mathrm{H}_{2} \mathrm{O}$. Samples were resuspended in $100 \mu \mathrm{l}$ of dd $\mathrm{H}_{2} \mathrm{O}$, and pipetted onto a microscope glass slide. The air-dried slides were incubated in bismark brown $(0.8 \%)$ for $8 \mathrm{~min}$ at $40{ }^{\circ} \mathrm{C}$, and then in rose bengal $(0 \cdot 8 \%)$ for $25 \mathrm{~min}$ at room temperature. Slides were washed to remove excess stain, passed twice through absolute ethanol for dehydration, and cleared twice in xylene (100\%). Four hundred spermatozoa were examined by light microscopy under oil immersion $(1000 \times)$ to record the acrosome status as described before (Rotem et al. 1992). This method assays the acrosome reaction in viable sperm. For the capacitation, pig sperm were washed twice and resuspended in mTBM medium containing $5 \mathrm{mg} / \mathrm{ml} \mathrm{BSA}$, and/or $1 \mathrm{nM}$ ANP for $60 \mathrm{~min}$ at $37^{\circ} \mathrm{C}$. At the end of incubation, sperm were exposed to lysophosphatidylcholine (LC; Parrish et al. 1988) for further $15 \mathrm{~min}$. The acrosome reaction was determined by triple-stain method.

\section{Oocyte collection and IVM}

Immature oocytes were aspirated from 3- to 6- $\mathrm{mm}$ follicles of abattoir-derived ovaries. Oocytes with uniform ooplasm and compact cumulus were collected and washed in IVM medium. Groups of 50 oocytes were transferred into an individual well of a four-well Nunclon dish with $0.5 \mathrm{ml}$ maturation medium. The culture was carried out at $39{ }^{\circ} \mathrm{C}$ in an atmosphere with $5 \% \mathrm{CO}_{2}$ in air for $44 \mathrm{~h}$.

In vitro fertilisation and embryo culture

Oocytes were stripped of cumulus cells by pipetting with $0 \cdot 1 \%(\mathrm{w} / \mathrm{v})$ hyaluronidase at the end of culture. 
Thereafter, oocytes were rinsed and 25-30 oocytes were transferred into $50 \mu \mathrm{l}$ droplets of the mTBM medium with $0.5 \%$ BSA plus $2 \mathrm{mM}$ caffeine, or $1 \mathrm{nM}$ ANP and/or $1 \mu \mathrm{M}$ KT5823. These droplets were covered with mineral oil (Sigma) and equilibrated for $40 \mathrm{~h}$ at $39{ }^{\circ} \mathrm{C}$ in $5 \% \mathrm{CO}_{2}$ in air. The dishes were kept in a $\mathrm{CO}_{2}$ incubator until sperm were added for insemination. Spermatozoa were incubated with $\mathrm{mTBM}$ medium containing different drugs to a concentration of $6 \times 10^{5}$ cells $/ \mathrm{ml}$, and $50 \mu \mathrm{l}$ of the sperm sample was added to the same fertilisation droplets containing the oocytes. Six $\mathrm{h}$ postinsemination (p.i.), oocytes were washed three times and cultured in $0.1 \mathrm{ml}$ droplets in embryo culture medium. All gamete incubations were performed in microdrops under mineral oil equilibrated at $39{ }^{\circ} \mathrm{C}$ in an atmosphere of $5 \% \mathrm{CO}_{2}$ in air. Some oocytes were fixed at $12 \mathrm{~h}$ p.i. in acetic ethanol $(25 \%, v / v)$ to assess meiotic stages, spermatozoa penetration rate, and the incidence of polyspermy, as described previously by Hunter \& Polge (1966). Oocytes were considered penetrated when one or more decondensed spermatozoa heads and/or male pronuclei and corresponding spermatozoa tails were present. The rate of polyspermy was determined from the number of oocytes penetrated. Cleavage was examined at $48 \mathrm{~h}$ p.i., and blastocyst formation was examined at $144 \mathrm{~h}$ p.i (Wu et al. 2002). Only embryos with blastomeres of equal diameter were counted as cleavage rate. Embryos or oocytes found to be degenerated or fragmented were not included (Kikuchi et al. 2002). Apparent blastocysts were stained with Hoechst 33342 and mounted on slides for counting of cell nuclei. Blastocyst formation rate was calculated as a percentage of the total number of oocytes inseminated.

\section{Experimental design}

Experiment 1: The expressions of ANP gene, NPRA gene and NPRC gene in pig spermatozoa and oviduct In order to determine whether ANP mRNA, NPRA mRNA or NPRC mRNA was expressed in pig spermatozoa and oviduct, total RNA was extracted from cells of $1 \mathrm{ml}$ fresh semen (the average density was $\left.145 \pm 36 \times 10^{6} / \mathrm{ml}, n=3\right)$ and oviducts at different stages, and RT-PCR was performed with ANP, NPRA and NPRC primers, respectively.

\section{Experiment 2: Immunodetection of ANP in pig} spermatozoa and oviduct To determine whether there is a potential physiological role for ANP in the oviduct during fertilisation, we detected the level of ANP in pig spermatozoa and oviduct. Proteins were extracted from cells of fresh pig semen and oviducts at different stages, and immunodetection of ANP was performed by SDS-PAGE.

Experiment 3: Effects of ANP, C-ANP-(4-23) and caffeine on the acrosome reaction of pig spermatozoa Sperm was incubated in $\mathrm{mTBM}$ containing $5 \mathrm{mg} / \mathrm{ml} \mathrm{BSA}$ for $2.5 \mathrm{~h}$ at a temperature of $37{ }^{\circ} \mathrm{C}$ and sperm viability was examined with $0.4 \%$ trypan blue. Pig sperm were then incubated in $\mathrm{mTBM}$ containing $5 \mathrm{mg} / \mathrm{ml}$ BSA supplemented with various doses of ANP, C-ANP-(4-23) (an analogue of ANP that specifically binds to the NPRC receptors), or $2 \mathrm{mM}$ caffeine for further $60 \mathrm{~min}$ at $37^{\circ} \mathrm{C}$. Same dose of vehicle was added to the control group at the same time. Acrosomal sperm status was analyzed by the triple-stain technique as described by Talbot \& Chacon (1981) and Rotem et al. (1998). The motility of sperm was also evaluated.

Experiment 4: The possible pathway of ANP on the acrosome reaction of pig sperm As ANP could bind to its specific cell-surface receptors (natriuretic peptide receptors-A; NPRA) and activate particulate guanylate cyclase and stimulate cGMP to produce a physiological response, we used permeable cGMP analog 8-Br-cGMP to mimic the effect of ANP on acrosome reaction. After incubation in mTBM medium containing $5 \mathrm{mg} / \mathrm{ml}$ BSA for $2.5 \mathrm{~h}$ at a temperature of $37^{\circ} \mathrm{C}$, pig sperm were then incubated with $0 \cdot 1,0 \cdot 5,1$ and $5 \mathrm{mM}$ cGMP for further $60 \mathrm{~min}$ at $37^{\circ} \mathrm{C}$ (Rotem et al. 1998) and acrosomal sperm status was analyzed by the triple-stain technique. The involvement of cGMP-dependent protein kinase (PKG) pathway in ANP-induced acrosome reaction was also tested by incubation of $1 \mathrm{nM}$ ANP, $1 \mu \mathrm{M}$ KT5823 (Pandey et al. 2000), and/or 0.5 $\mu \mathrm{M}$ Rp-8-pCPT-cGMPS (for review, see Smolenski et al. 1998) for further $60 \mathrm{~min}$ at $37^{\circ} \mathrm{C}$. Same dose of vehicle was added to the control group at the same time. The possible effect of cAMP-dependent protein kinase (PKA) pathway in the high concentration of 8 -Br-cGMP $(1 \mathrm{mM})$ was also studied by PKA inhibitor H89 (0.05 $\mu \mathrm{M}$; for review, see Smolenski et al. 1998).

Experiment 5: Effect of ANP on the capacitation The possible effect of ANP on the capacitation was studied by lysophosphatidylcholine. Pig sperm were washed twice and resuspended in MTBM medium containing $5 \mathrm{mg} / \mathrm{ml} \mathrm{BSA}$, and/or $1 \mathrm{nM}$ ANP for $60 \mathrm{~min}$ at $37^{\circ} \mathrm{C}$. At the end of incubation, sperm were exposed to 0 or $100 \mu \mathrm{g} / \mathrm{ml} \mathrm{lysophosphatidylcholine} \mathrm{for} \mathrm{further} 15 \mathrm{~min}$. The acrosome reaction was determined by triple-stain method.

Experiment 6: Effect of ANP on in vitro fertilisation Spermatozoa were incubated in mTBM medium containing $5 \mathrm{mg} / \mathrm{ml}$ BSA supplemented with $2 \mathrm{mM}$ caffeine, $1 \mathrm{nM}$ ANP and/or $1 \mu \mathrm{M}$ KT5823 for $90 \mathrm{~min}$ at $37^{\circ} \mathrm{C}$, and then $50 \mu$ of the sperm sample $\left(6 \times 10^{5}\right.$ cells $\left./ \mathrm{ml}\right)$ was added to the same fertilisation droplets containing the oocytes. Same dose of vehicle was added to the control group. As the total incubation time is $7.5 \mathrm{~h}$, sperm was not preincubated before drug treatments. The proportions of 
(A)

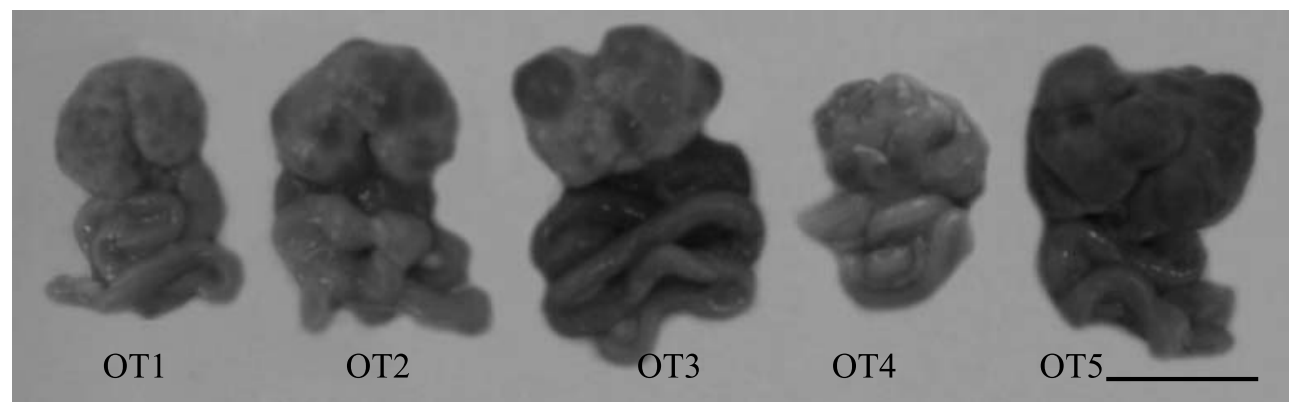

(B)
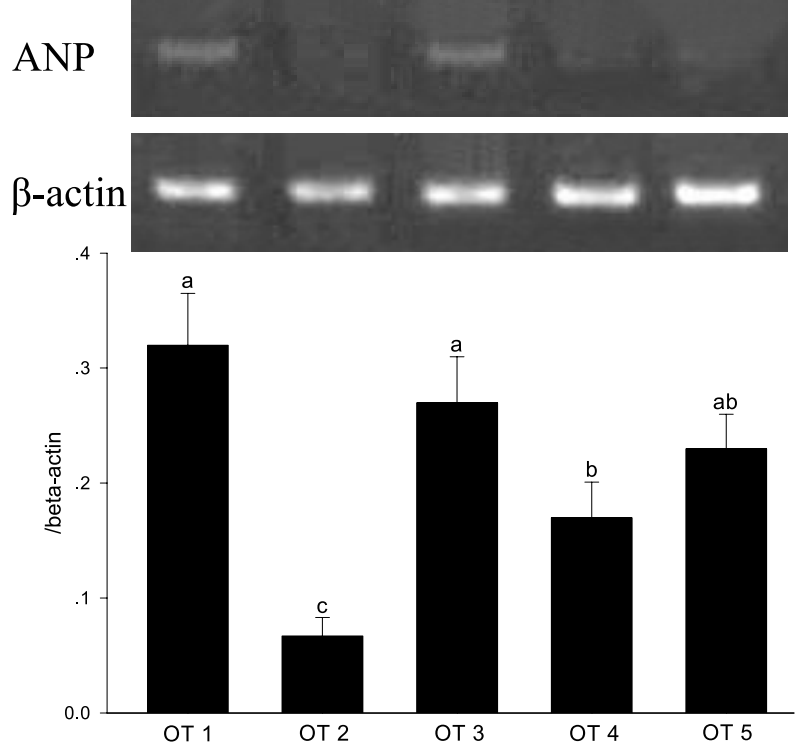

$(D)$

NPRC
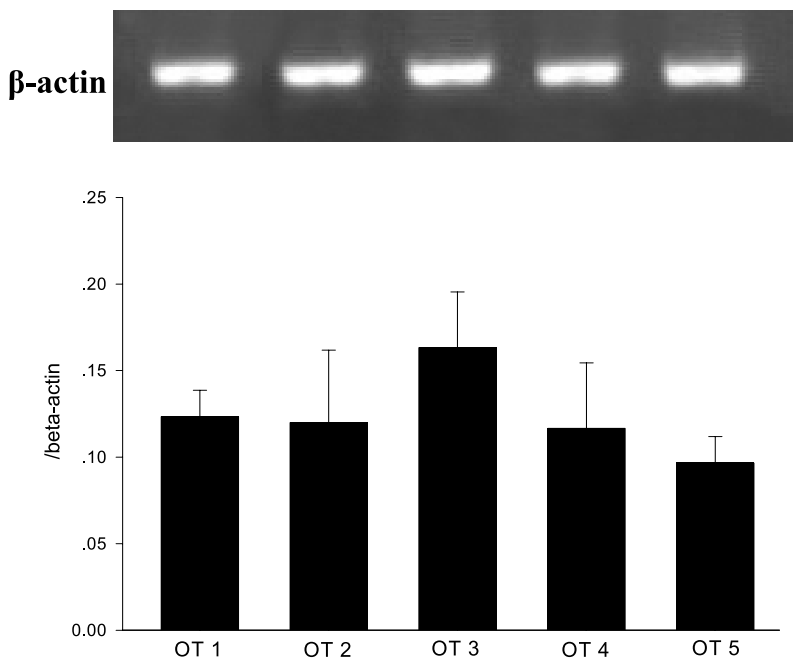

(C)
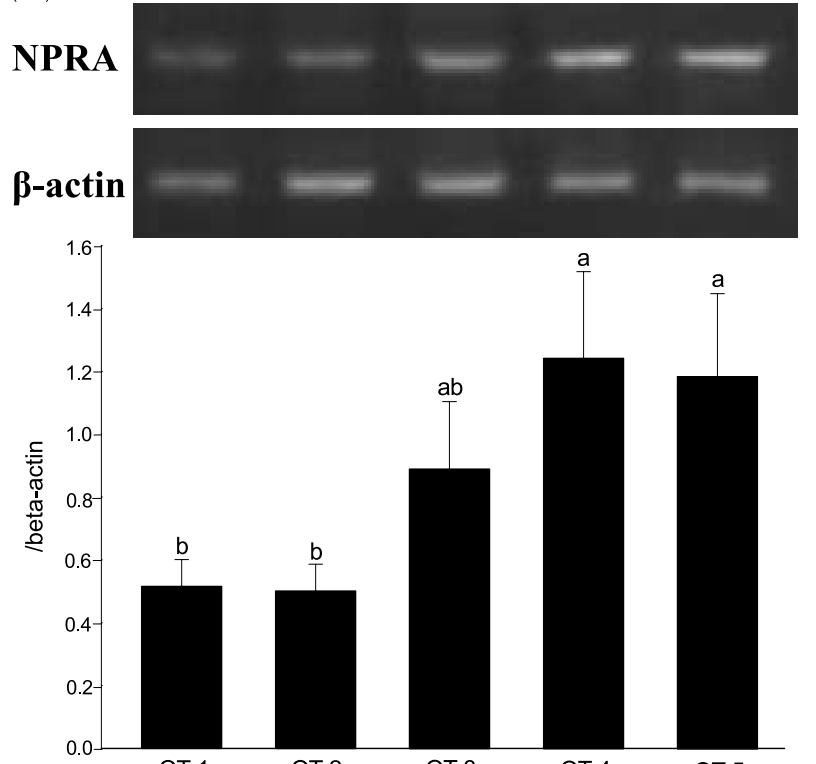

OT 1

OT 3

OT 4

OT 5

Figure 1 The expressions of ANP gene, NPRA gene and NPRC gene in the oviduct. (A) According to the follicular characterization in the ovary, the five oviductal phases throughout the estrous cycle were defined as OT1, OT2, OT3, OT4 and OT5. (B) RT-PCR analysis of ANP in the oviduct. The intensity of the amplified bands was quantified by densitometric scanning. The respective value of either ANP was normalized according to those of beta-actin to evaluate arbitrary units of the relative abundance of the targets. The means \pm S.E.M. have been calculated in three independent experiments. Values with different superscripts differ significantly $(P<0 \cdot 05)$. (C) RT-PCR analysis of NPRA in the oviduct. The intensity of the amplified bands was quantified by densitometric scanning. Values with different superscripts differ significantly $(P<0 \cdot 05)$. (D) RT-PCR analysis of NPRC in the oviduct. The intensity of the amplified bands was quantified by densitometric scanning. No obvious change was observed among the five oviductal phases. 
oocyte penetration, cleavage and blastocyst formation were examined at $12 \mathrm{~h}, 48 \mathrm{~h}$ and $144 \mathrm{~h}$, respectively.

\section{Statistical analysis}

Experiments were performed with different semen and oocyte samples. Results are given as the mean \pm S.E.M. of at least three experiments, with each assessment done in triplicate. All proportional data were subjected to an arcsine transformation and analyzed by ANOVA using StatView software (SAS Institute, Inc, Cary, NC, USA). When there was a significant $\mathrm{F}$ ratio, groups were compared using Fisher's protected least significant difference post hoc test. Statistical significance was defined as $P<0 \cdot 05$.

\section{Results}

The expressions of ANP gene, NPRA gene and NPRC gene in pig spermatozoa and oviduct

After washed with Percoll technique, little seminal plasma particulate material (such as spermatogenic cells, neutrophils and/or cytoplasmic droplets) was observed in the semen. Partial cDNAs were amplified by RT-PCR from pig spermatozoa and oviduct using each primer set corresponding to the sequences of porcine ANP, human NPRA and rat NPRC, respectively (Table 1, Fig. 1, Fig. 2). The partial porcine ANP sequence was the same as that reported by Mägert et al. (1990). The partial porcine NPRA sequence showed a high degree of similarity to human $(94 \cdot 1 \%)$, mouse $(89 \cdot 6 \%)$, and rat $(90 \cdot 0 \%)$ sequences (Fig. 2B). The partial porcine NPRC sequence also showed a high degree of similarity to human $(92 \cdot 3 \%)$, mouse $(91 \cdot 3 \%)$, and rat $(90 \cdot 8 \%)$ sequences (Fig. 2C). Sequence comparisons indicate that the partial porcine cDNAs amplified with either NPRA primer or NPRC primer conformed to the porcine NPRA region or the NPRC region, respectively. Fig. 2A shows that the ANP gene, NPRA gene and NPRC gene were expressed at all stages of the oviducts, but only NPRA mRNA was detected in the spermatozoa. The levels of the ANP gene expression were high in OT1, dramatically decreased in OT2, and then increased in OT3 (Fig. 1B). The levels of the NPRA gene expression were low in OT1 and OT2, gradually increased in OT3, and then reached a maximum in OT4 and OT5 (Fig. 1C). The levels of the NPRC gene expression were low without obvious change among all phases of the oviduct (Fig. 1D).

\section{Immunodetection of ANP in pig spermatozoa and oviduct}

Western blot analysis revealed that ANP protein was not detected in spermatozoa but existed in all stages of the oviduct (Fig. 3). The highest level of ANP was detected at

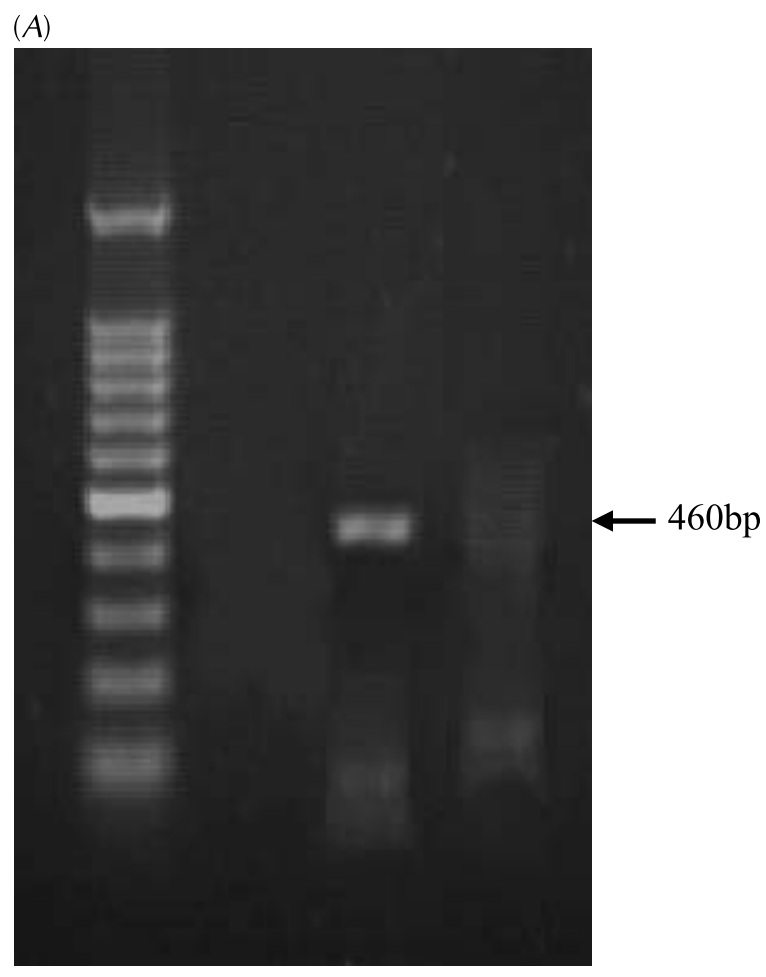

ANP NPRA NPRC

Figure 2A The expressions of ANP gene, NPRA gene and NPRC gene in pig spermatozoa. (A) RT-PCR analysis of ANP mRNA, NPRA mRNA and NPRC mRNA in pig spermatozoa.

OT1 stage. The level of ANP at OT4 and OT5 stages was lower than that at OT1 $(P<0 \cdot 01)$, OT2 $(P<0 \cdot 05)$ and OT3 $(P<0 \cdot 05)$ stages.

\section{ANP induced acrosome reaction of pig spermatozoa}

The motility of fresh sperm was $92.5 \pm 2 \cdot 9 \%$. After incubated, the motilities of sperm in control, ANP $(1 \mathrm{nM}), \mathrm{C}-\mathrm{ANP}-(4-23)(1 \mathrm{nM})$ and caffeine treatment were $82 \cdot 5 \pm 2 \cdot 9 \%, \quad 78 \cdot 8 \pm 4 \cdot 8 \%, \quad 80 \cdot 0 \pm 4 \cdot 1 \%$ and $83 \cdot 8 \pm 4 \cdot 8 \%$, respectively. Preincubated sperm were incubated with various concentrations of ANP for $1 \mathrm{~h}$, and the proportion of spermatozoa that underwent the acrosome reaction was increased $(P<0.01)$ by incubation with $0 \cdot 1 \mathrm{nM}$ ANP $(26 \cdot 2 \pm 2 \cdot 2 \%)$ or $1 \mathrm{nM}$ ANP $(34 \cdot 1 \pm 2 \cdot 3 \%)$ compared with untreated cells $(16.5 \pm 1 \cdot 8 \%$; Fig. 4)The maximal proportion of spermatozoa that underwent the acrosome reaction $(\sim 2 \cdot 0$-fold relative to controls) was detected at $1 \mathrm{nM}$ ANP, while C-ANP-(4-23) (in concentrations that ranged from $10 \mathrm{pM}$ to $100 \mathrm{nM}$ ) and caffeine $(2 \mathrm{mM})$ had no effect on the acrosome reaction (Fig. 4, Fig. 5 and data not shown).

Role of cGMP in ANP-induced acrosome reaction

Permeable cGMP analog 8-Br-cGMP was used to mimic the effect of ANP on acrosome reaction of 
(B)

Porcine: GAGCCCAGTA GCCTTGAGAG GCACCTCCGG AATGCGGGCA GCCGGCTGAC CCTGAGTGGG

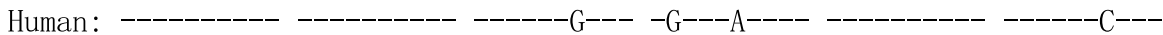

Mouse: C------- $\mathrm{C}-----\mathrm{G}-----------\mathrm{T}----\mathrm{GC}--\mathrm{T}-----\mathrm{T}---------~----------$

Rat: $\mathrm{C}--------\mathrm{C}-----\mathrm{G}^{------}---\mathrm{T}--\mathrm{T}----\mathrm{GC}--\mathrm{T}--------------------------$

Porcine: AGAGGCTCCA ATTACGGCTC CCTGCTGACC ACAGAGGGCC AGTTCCAAAT CTTTGCCAAG

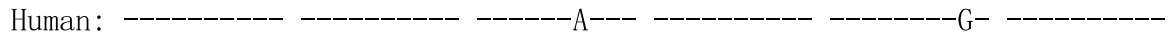

Mouse: $\mathrm{C}--------------\mathrm{T}^{------}-------\mathrm{A}-----\mathrm{G}^{--------}--------\mathrm{G}^{-}-----------$

Rat: $\mathrm{C}--------------\mathrm{T}------------\mathrm{A}^{---}--\mathrm{C}---------------\mathrm{G}^{-}----------$

Porcine: ACAGCGTATT ATAAGGGCAA CCTCGTGGCT GTGAAACGTG TCAACCGGAA ACGCATTGAG

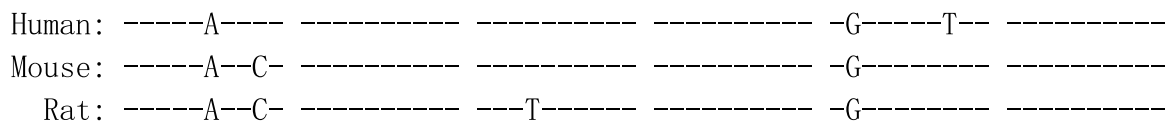

Porcine: CTGACGCGGG AAGTCCTGTT TGAACTGAAG CATATGCGGG ATGTGCAGAA TGAACACCTG

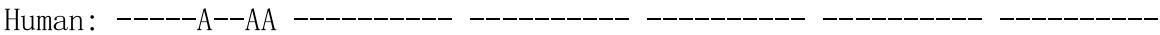

Mouse: $\mathrm{T}----\mathrm{A}--\mathrm{AA}----------------\mathrm{T}--\mathrm{A}---------------------~---\mathrm{G}^{--} \mathrm{AT}--$

Rat: $\mathrm{T}----\mathrm{A}--\mathrm{AA}----------------\mathrm{T}-\mathrm{A}-----------------------\mathrm{G}^{---} \mathrm{T}--$

Porcine: ACCAGGTTTG TGGGGGCCTG CACTGATCCC CCCAACATCT GTATCCTCAC GGAGTACTGT

Human: ---------- ---- $\mathrm{A}^{------}---\mathrm{C}^{--} \mathrm{C}---------\mathrm{T}^{----}-\mathrm{C}^{---------} \mathrm{A}^{---}-------$

Mouse: $-----\mathrm{A}--------\mathrm{A}--\mathrm{T}--\mathrm{T}-\mathrm{C}--\mathrm{C}-\mathrm{T}---------------------\mathrm{A}----------$

Rat: $--\mathrm{A}--\mathrm{A}--------\mathrm{T}--\mathrm{T}--\mathrm{T}--\mathrm{C}--\mathrm{C}-----------------------\mathrm{A}_{---------}$

Porcine: CCCCGTGGGA GCCTACAGGA CATTCTGGAG AATGAGAGCA TCACGCTGGA CTGGATGTTC

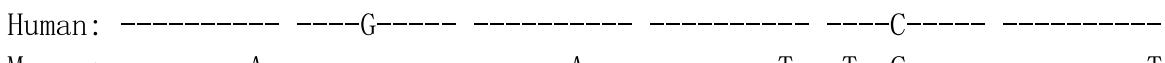

Mouse: ---------A- ----------- ------ $\mathrm{A}------------\mathrm{T}-\mathrm{T}-\mathrm{T}-\mathrm{C}----------------\mathrm{T}$

Rat: --------A- ---------- ------A--- -------- $\mathrm{T}-----\mathrm{C}--------------\mathrm{T}$

Porcine: CGGTACTCGC TCACCAACGA CATCGTCAAG GGCATGCTGT TCCTGCACAA TGGGGCCATT 420

Human: --------A- ------- $\mathrm{T}-----------------------\mathrm{T}_{--} \mathrm{A}------------\mathrm{T}--\mathrm{C}$

Mouse: $---------\mathrm{A}--------\mathrm{T}-----\mathrm{T}--------\mathrm{A}^{-----} \mathrm{C}-\mathrm{T}-\mathrm{T}--\mathrm{A}------\mathrm{C}---------$

Rat: ---------- ------- $\mathrm{T}-----\mathrm{T}--------\mathrm{A}-----\mathrm{C}-\quad-\mathrm{T}--\mathrm{A}----------------$

Porcine: TGCTCCCATG GGAACCTCAA GTCATCCAAC TGCGTGGTAG

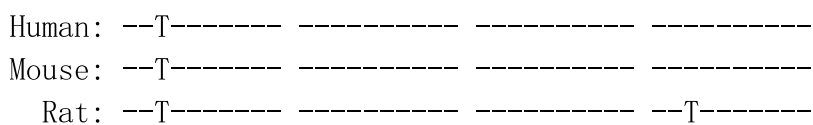

Figure 2B The expressions of ANP gene, NPRA gene and NPRC gene in pig spermatozoa. (B) Comparison of partial cDNA sequences of NPRA primers-RT-PCR with human NPRA (accession no. NM000906), mouse NPRA (accession no. NM008727), or rat NPRA (accession no. NM012613).

pig spermatozoa. As shown in Fig. 6, incubation with 8-Br-cGMP $(0 \cdot 1-5 \mathrm{mM})$ caused a similar effect on spermatozoa acrosome reaction as that incubated with ANP, and the maximal proportion of spermatozoa that underwent the acrosome reaction was detected at $1 \mathrm{mM}$ 8 -Br-cGMP $(25 \cdot 7 \pm 2 \cdot 1 \%)$.
The effect of PKG inhibitors on ANP-induced acrosome reaction

ANP interacts with the ANP receptor, with subsequent generation of cGMP in target cells. The PKG inhibitors KT5823 and Rp-8-pCPT-cGMPS were used to test the 
(C)

Porcine: GGGCAGTGAG CGAGTGGTGA TCATGTGTGC GAGCAGCGAC ACCATCCGCA GCATCATGCT

Mouse: $\mathrm{A}------\mathrm{C}---------------$

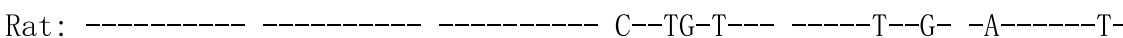

Porcine: GGCGGCCCAC AGGCACGGGA TGACCAGCGG AGACTACGCC TTCTTCAACA TTGAGCTCTT

Human: --T---G--- -----T-C- -------T-- ---------- ---------- ----------

Mouse: $-----\mathrm{TG}^{---}--\mathrm{A}^{-----} \mathrm{C}-{ }_{-------} \mathrm{T}------------\mathrm{T}---------------\mathrm{A}-----$

Rat: $-----\mathrm{TG}^{---}--\mathrm{A}^{-----} \mathrm{C}--------\mathrm{T}--------\mathrm{T}--\mathrm{T}--------------\mathrm{A}^{------}$

Porcine: CAACAGCTCT TCTTACGGAG ATGGCTCATG GAGGAGAGGA GACAAGCACG ACTTTGAAGC

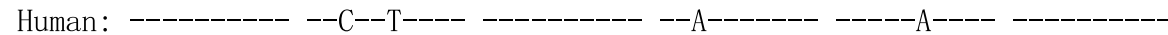

Mouse: $------\mathrm{T}-----\mathrm{C}^{--------}-------\mathrm{G}^{--}-----------\quad-----\mathrm{A}^{----}---\mathrm{C}^{-------}$

Rat: $------\mathrm{T}--------------------\mathrm{G}^{--}---\mathrm{A}------\mathrm{G}-----\mathrm{A}---------------$

Porcine: TAAGCAAGCG TACTCATCCC TCCAAACAAT CACTCTACTG AGGACAGTGA AACCTGAGTT

Human: ----------A $-----\mathrm{G}^{-----}----\mathrm{G}^{---} \mathrm{G}-$

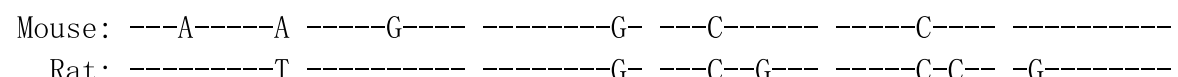

Porcine: TGAGAAGTTT TCCATGGAGG TGAAAAATTC TGTTGAGAAG CAAGGGCTCA GTGAGGAGGA

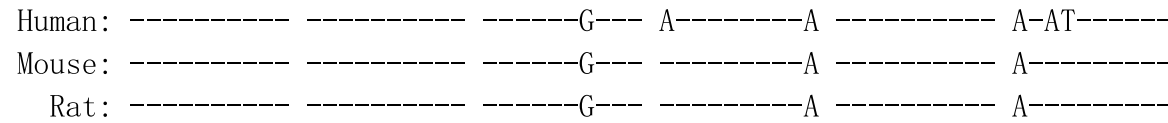

Porcine: TTACGTGAAC ATGTTTGTTG AAGGATTCCA CGACGCCATC CTCCTCTACG TCCTGGCTTT 360

Human: ------T--- ---------- ---------- $---\mathrm{T}-------\quad------------\mathrm{T}-----\mathrm{C}-$

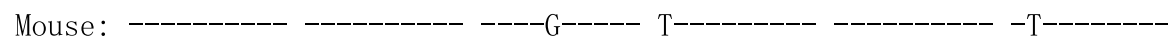

Rat: $---------------\mathrm{C}--------\mathrm{C}^{-----} \mathrm{T}--\mathrm{T}------------------\mathrm{T}---------$

60

orcine: ACATGAAGTG CTCAGAGCTG GCTACAGCAA GAAGGATGGG G

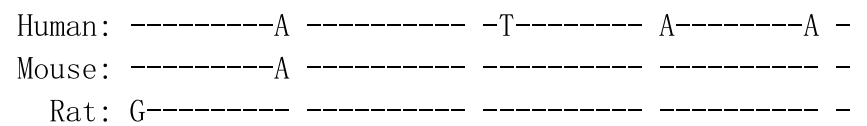

Figure 2C The expressions of ANP gene, NPRA gene and NPRC gene in pig spermatozoa. (C) Comparison of partial cDNA sequences of NPRC primers-RT-PCR with human NPRC (accession no. NM000908), mouse NPRC (accession no. AF131864), or rat NPRC (accession no. NM012868).

involvement of PKG pathway in ANP-induced acrosome reaction. The possible effect of PKA pathway in the high concentration of $8-\mathrm{Br}-\mathrm{cGMP}(1 \mathrm{mM})$ was also studied by a PKA inhibitor H89. As shown in Fig. 7, both KT5823 $(1 \mu \mathrm{M})$ and Rp-8-pCPT-cGMPS $(0.5 \mu \mathrm{M})$ could completely abolish ANP-induced acrosomal exocytosis of pig spermatozoa, but each alone had no effect on the acrosome reaction. On the other hand, H89 $(0 \cdot 05 \mu \mathrm{M})$ could not block the effect of 8 -Br-cGMP on the acrosome reaction.
The effect of $A N P$ on the capacitation

The possible effect of ANP on the capacitation was studied by lysophosphatidylcholine. Compared with control, incubation of lysophosphatidylcholine for $15 \mathrm{~min}$ had a significant effect on the percentage of sperm that were acrosome-reacted $(P<0 \cdot 05$. Fig. 8). However, lysophosphatidylcholine had no obvious effect on the acrosome reaction when sperm were preincubated with ANP. Addition of $100 \mu \mathrm{g} / \mathrm{ml}$ lysophosphatidylcholine for 

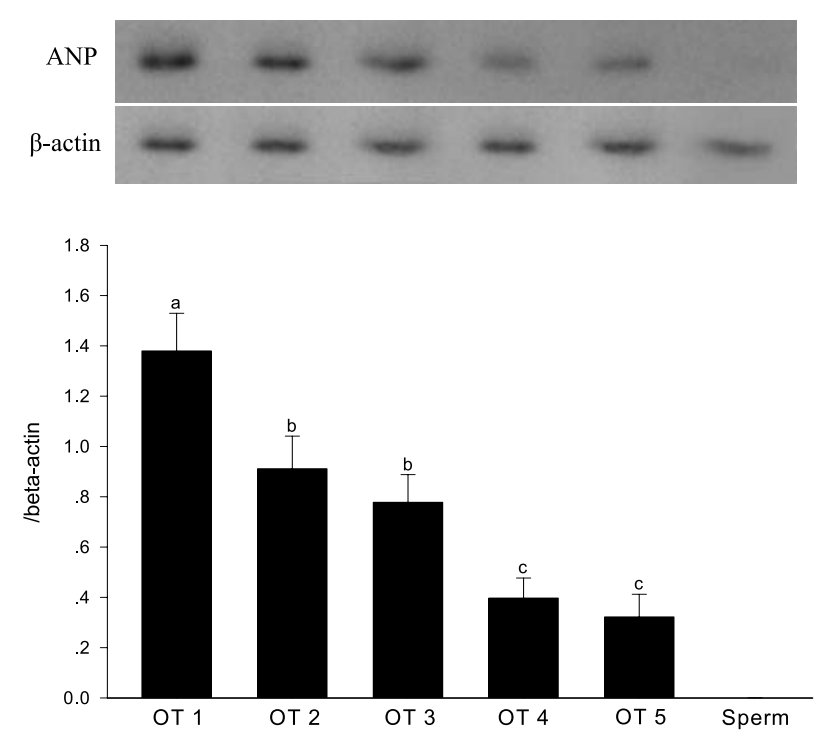

Figure 3 Immunodetection of ANP in pig spermatozoa and oviduct. The intensity of the amplified bands was quantified by densitometric scanning. Autoradiogram reflects a representative experiment and bar graphs represent the mean of three independent experiments. The respective value of either ANP was normalized according to those of beta-actin to evaluate arbitrary units of the relative abundance of the targets. Values in different oviduct stages with different superscripts differ significantly $(P<0 \cdot 05)$. The level of ANP was not detected in spermatozoa.
$15 \mathrm{~min}$ alone had no effect on the percentage of sperm that were motile or acrosome-reacted (data not shown).

\section{ANP induces fertilising ability of pig spermatozoa}

As shown in Table 2, the presence of ANP or caffeine in insemination medium resulted in a higher proportion $(P<0 \cdot 05)$ of oocytes penetrated and polyspermy, and also resulted in a higher $(P<0 \cdot 05)$ average number of spermatozoa per penetrated oocyte. The effect of ANP was completely inhibited by KT5823, but KT5823 alone had no effect on these fertilisation parameters. There were no differences between ANP and caffeine treatments in the proportion of oocytes penetrated and polyspermy, the average number of sperm per penetrated oocytes, cleavage rate, blastocyst formation rate or the number of cells per blastocyst (Table 2, Table 3, Fig. 9).

\section{Discussion}

It has been reported that the sperm not only contribute the haploid male genome, but also deliver messenger RNAs to the oocyte at fertilisation (Ostermeier et al. 2004), suggesting that the messenger RNAs of the sperm may play an important role in fertilisation (Ostermeier et al. 2002). In the present study, we examined the

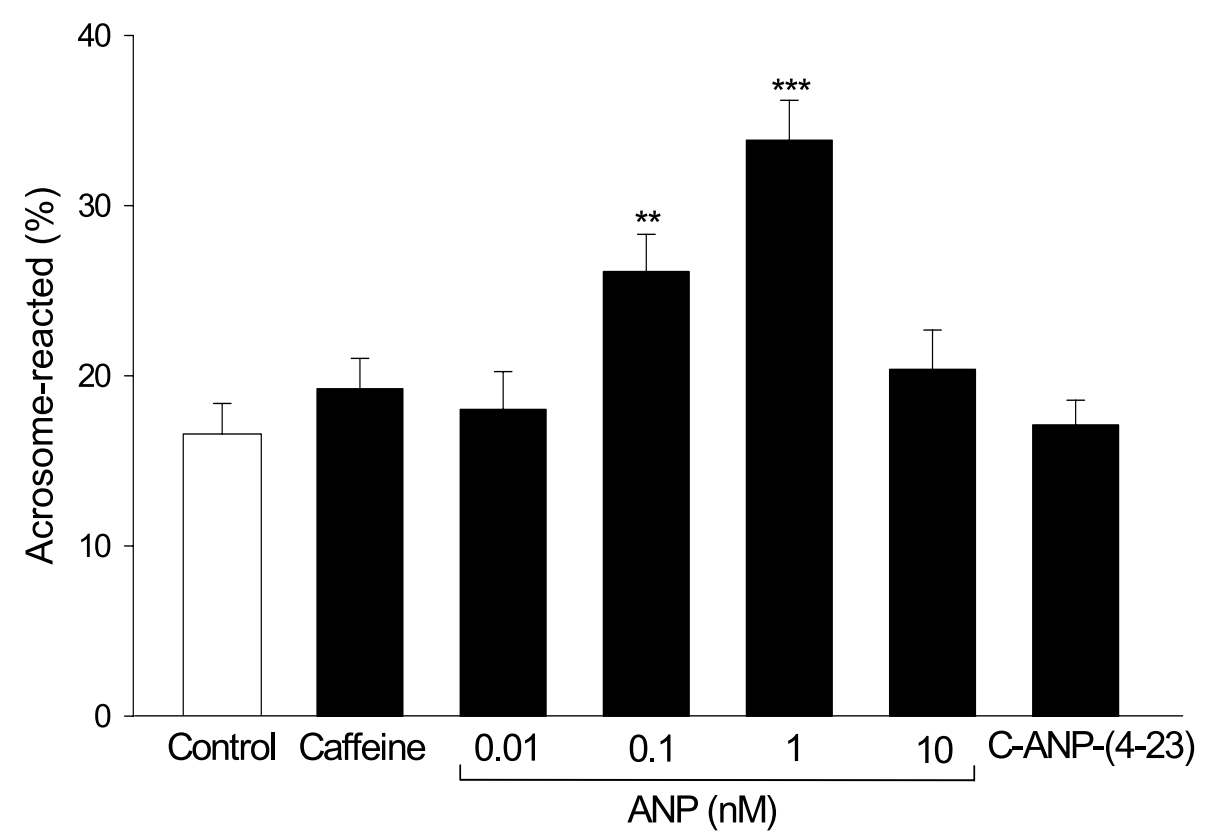

Figure 4 Effects of ANP, caffeine and C-ANP-(4-23) on the acrosome reaction. Pig semen were washed twice with mTBM medium containing $5 \mathrm{mg} / \mathrm{ml} \mathrm{BSA}$ and then incubated in this medium for $2.5 \mathrm{~h}$. Sperm $\left(1 \times 10^{8} /\right.$ tube $)$ were then washed again and incubated at $37^{\circ} \mathrm{C}$ for 60 min with increasing concentrations of ANP, caffeine or C-ANP-(4-23). The acrosome reaction was determined by triple-stain method. Results are means \pm S.E.M. of three experiments, with at least 400 spermatozoa counted per replicate $(n=3)$. ${ }^{* *} P<0 \cdot 01$; ${ }^{* *} P<0 \cdot 001$ versus control. 


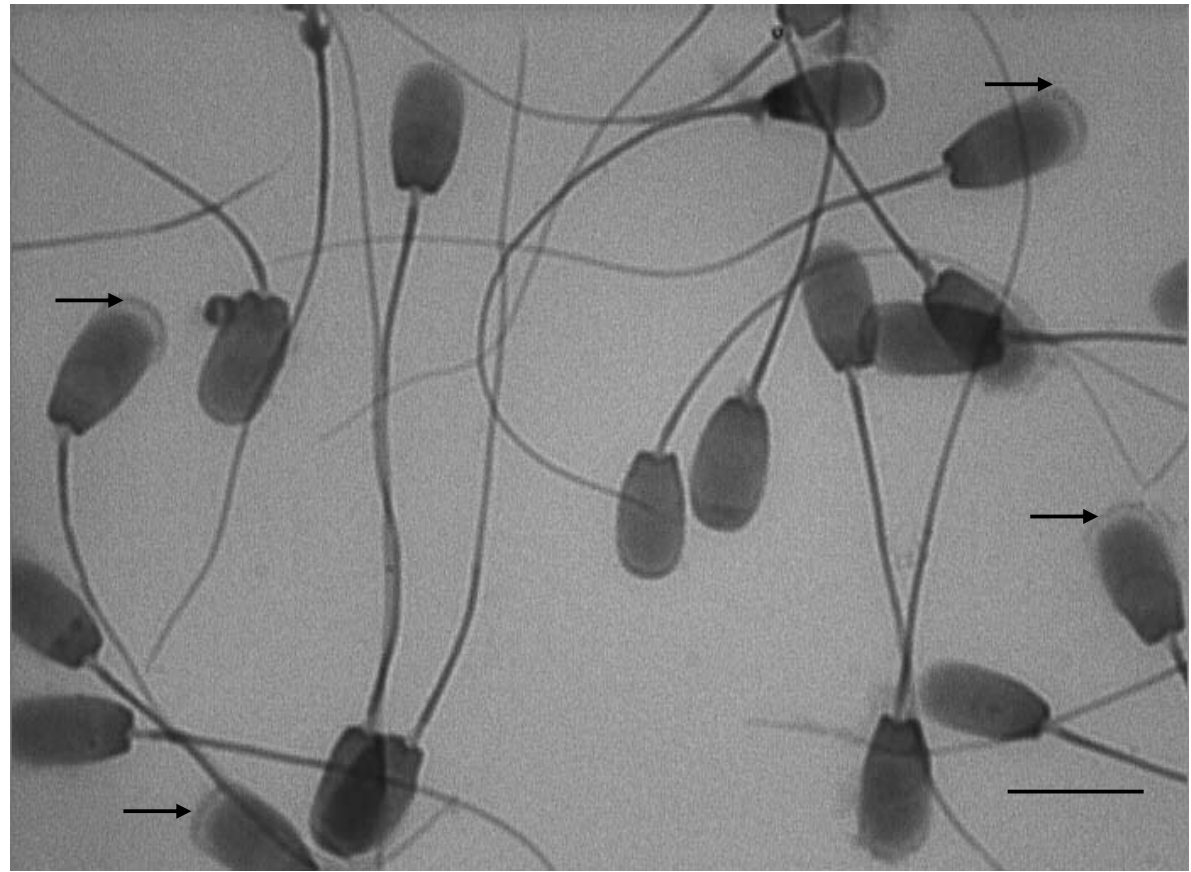

Figure 5 Image of ANP-induced acrosomal sperm status. Preincubated sperm were further incubated with $1 \mathrm{nM}$ ANP $60 \mathrm{~min}$, and the acrosomal sperm status was determined by triple-stain method. Arrow points to the acrosome-reacted sperm with white acrosomal region. Bar $=10 \mu \mathrm{m}$.

expressions of the ANP gene, the NPRA gene and the NPRC gene, and only NPRA mRNA was detected in pig spermatozoa. Western blot analysis further indicated that ANP protein did not exist in the spermatozoa. Our results are consistent with previous reports that a single class of ANP receptors (NPRA) is detected in human spermatozoa (Silvestroni et al. 1992, WillipinskiStapelfeldt et al. 2004), and that ANP-induced acrosome

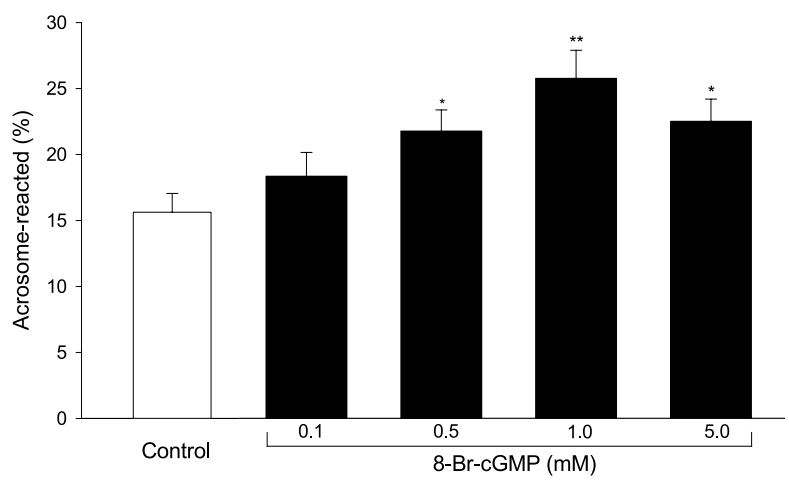

Figure 6 Effect of 8-Br-cGMP on the acrosome reaction. Pig spermatozoa were preincubated and then further incubated with increasing doses of permeable cGMP analog 8-Br-cGMP for $60 \mathrm{~min}$. The acrosome reaction was determined by triple-stain method. Results are means \pm S.E.M. of three experiments, with at least 400 spermatozoa counted per replicate $(n=3) .{ }^{*} P<0 \cdot 05$; ${ }^{* *} P<0.01$ versus control. reaction via the elevation of cGMP could be completely inhibited by the selective NPRA antagonist anantin (Anderson et al. 1994, Rotem et al. 1998). We also examined the changes of the ANP protein, ANP mRNA, NPRA mRNA and NPRC mRNA in the oviduct. The oviduct was divided into five phases by the follicular characterization in the ovary, which may present the different stages of estrous cycle. The data revealed that the levels of both ANP mRNA and ANP protein were obviously high in OT1, consistent with a previous report that the concentration of ANP in rat oviduct is significantly elevated at the diestrus stage of the estrous cycle (Kim et al. 1997). The level of ANP protein in OT3 was lower than that in OT1, but was higher than that in OT4 and OT5. Moreover, the level of ANP mRNA was dramatically increased in OT3. The expression of ANP in OT3 may play a physiological role in spermatozoa function, since the spermatozoa displayed NPRA gene expression but not the ANP gene expression. On the other hand, the expression of ANP gene may also be involved in the regulation of oviductal motility (Kim et al. 1997). The motility may be regulated by both ANP and NPRA, since we also detected the changes of ANP mRNA and NPRA mRNA among the different oviductal phases. The low levels of NPRC mRNA in the oviduct throughout estrous cycle are consistent with a previous report that ANP bindings in rat oviduct are not reversed by C-ANP(4-23), that specifically binds to NPRC (Kim et al. 1997). 


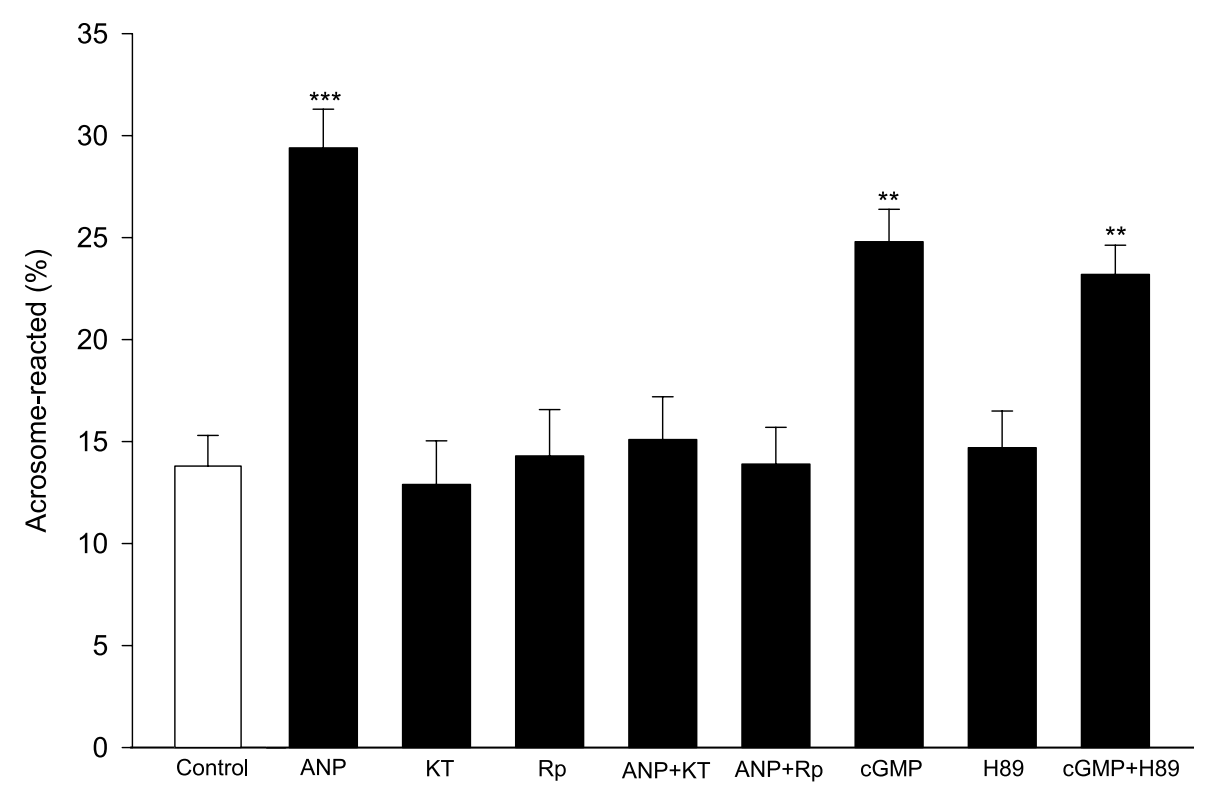

Figure 7 Effect of PKG inhibitors on an ANP-induced acrosome reaction. Pig spermatozoa were preincubated and then further incubated with ANP $(1 \mathrm{nM}), \mathrm{KT} 5823(1 \mu \mathrm{M})$, and/or Rp-8-pCPT-cGMPS $(0.5 \mu \mathrm{M})$ for $60 \mathrm{~min}$. The acrosome reaction was determined by triple-stain method. The possible effect of PKA pathway in the high concentration of 8-Br-cGMP (1 mM) treatment was also studied by PKA inhibitor H89 (0.05 $\mu \mathrm{M})$. Results are means \pm S.E.M. of three experiments, with at least 400 spermatozoa counted per replicate $(n=3)$. ${ }^{* *} P<0 \cdot 01$; ${ }^{* * *} P<0 \cdot 001$ versus control. KT, KT5823; Rp, Rp-8-pCPT-cGMPS; cGMP, 8-Br-cGMP.

The acrosome reaction enables the sperm cell to penetrate the zona pellucida (ZP) and to fuse with the egg's plasma membrane (Wassarman 1987, Yanagimachi 1994), which is essential for fertilisation. Therefore, elucidation of the mechanisms that control the acrosome reaction is important for understanding fertilisation. Multiple physiological agonists probably participate in the regulation of the acrosome reaction (Joyce et al. 1987, Wassarman 1987. Anderson et al. 1994, 1995, Roldan et al. 1994, Yanagimachi 1994, Zamir et al. 1995). ANP could serve as such a physiological agonist. In our study, ANP significantly induced acrosome reaction of preincubated pig spermatozoa; this effect was mimicked by 8 -Br-cGMP but abolished by the PKG inhibitors KT5823 and Rp-8pCPT-cGMPS. However, C-ANP-(4-23), that specifically binds to NPRC (Bovy et al. 1989), had no effect on the acrosome reaction, suggesting that the function of ANP on the acrosomal reaction may not be through the NPRC receptors. It is reported that ANP shows high affinity for natriuretic peptide receptors-A (NPRA) and NPRC receptors in various animals (for review, see Takei 2000), and induces the acrosome reaction of capacitated human spermatozoa by NPRA receptors and elevation of cGMP (Anderson et al. 1994, Rotem et al. 1998). We also showed that only NPRA mRNA was detected in pig spermatozoa. All these results indicate that the ANPinduced acrosome reaction of pig spermatozoa occurs via the NPRA/cGMP/PKG pathway. In contrast, it is shown

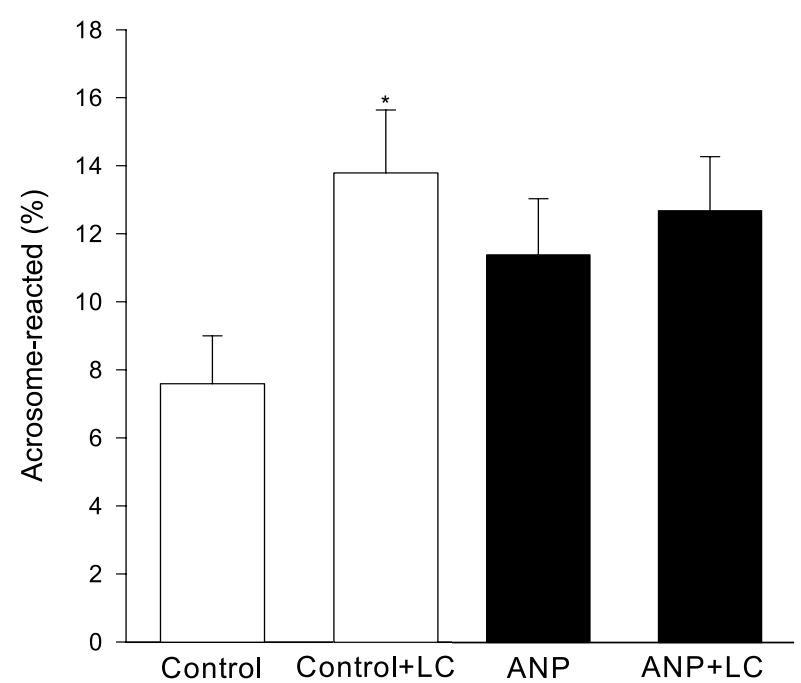

Figure 8 Effect of ANP on the capacitation. Pig sperm were washed twice and resuspended in mTBM medium containing $5 \mathrm{mg} / \mathrm{ml} \mathrm{BSA}$, and/or $1 \mathrm{nM}$ ANP for $60 \mathrm{~min}$ at $37^{\circ} \mathrm{C}$. At the end of incubation, sperm were exposed to 0 or $100 \mu \mathrm{g} / \mathrm{ml}$ lysophosphatidylcholine (LC) for a further $15 \mathrm{~min}$. The acrosome reaction was determined by triple-stain method. Results are means \pm S.E.M. of three experiments, with at least 400 spermatozoa counted per replicate $(n=3)$. ${ }^{*} P<0 \cdot 05$ versus control. 
Table 2 Effect of caffeine, ANP and/or KT5823 on fertilisation parameters of pig oocytes inseminated in $\mathrm{mTBM}$ medium

\begin{tabular}{|c|c|c|c|c|c|}
\hline & \multirow[b]{2}{*}{$n$} & \multicolumn{2}{|c|}{ Oocytes penetrated } & \multirow{2}{*}{$\begin{array}{l}\text { Polyspermy }{ }^{\dagger} \\
(\%)\end{array}$} & \multirow{2}{*}{$\begin{array}{l}\text { No. sperm/ } \\
\text { penetrated oocyte }\end{array}$} \\
\hline & & Total $(\%)$ & With MPN (\%) & & \\
\hline \multicolumn{6}{|l|}{ Treatment } \\
\hline Control $^{\ddagger}$ & 124 & $33 \cdot 4 \pm 2 \cdot 6^{b}$ & $79 \cdot 3 \pm 2 \cdot 8$ & $22 \cdot 4 \pm 1 \cdot 5^{b}$ & $1 \cdot 13 \pm 0 \cdot 14^{b}$ \\
\hline Caffeine $^{\S}$ & 121 & $72 \cdot 2 \pm 5 \cdot 0^{\mathrm{a}}$ & $84 \cdot 2 \pm 3 \cdot 4$ & $59 \cdot 6 \pm 6 \cdot 8^{a}$ & $2 \cdot 12 \pm 0 \cdot 35^{a}$ \\
\hline$A N P^{\S}$ & 118 & $75 \cdot 2 \pm 5 \cdot 3^{a}$ & $83 \cdot 6 \pm 2 \cdot 3$ & $62 \cdot 1 \pm 7 \cdot 8^{a}$ & $2 \cdot 24 \pm 0 \cdot 31^{\mathrm{a}}$ \\
\hline KT5823§ & 106 & $35 \cdot 5 \pm 3 \cdot 7^{\mathrm{b}}$ & $78 \cdot 6 \pm 3 \cdot 1$ & $24 \cdot 5 \pm 2 \cdot 7^{b}$ & $1 \cdot 06 \pm 0 \cdot 18^{\mathrm{b}}$ \\
\hline $\mathrm{ANP}+\mathrm{KT} 5823^{\S}$ & 110 & $38 \cdot 6 \pm 4 \cdot 1^{\mathrm{b}}$ & $81 \cdot 4 \pm 3 \cdot 7$ & $26 \cdot 3 \pm 3 \cdot 7^{b}$ & $1 \cdot 31 \pm 0 \cdot 22^{b}$ \\
\hline
\end{tabular}

Values with different superscripts $(a, b)$ within column differ significantly $(P<0 \cdot 05)$. MPN, male pronucleus. Experiments were repeated four times.

tPercentage of oocytes penetrated.

${ }^{\text {F}}$ Sperm were preincubated in mTBM containing $5 \mathrm{mg} / \mathrm{ml} \mathrm{BSA}$ for $90 \mathrm{~min}$, and then $50 \mu \mathrm{l}$ of the sperm sample was added to the same fertilisation droplets containing the oocytes.

${ }^{\S}$ Sperm were preincubated in mTBM containing $5 \mathrm{mg} / \mathrm{ml} \mathrm{BSA}$ supplemented with $2 \mathrm{mM}$ caffeine, $1 \mathrm{nM}$ ANP and/or $1 \mu \mathrm{M} \mathrm{KT5823} \mathrm{for} 90 \mathrm{~min}$, and then $50 \mu \mathrm{l}$ of the sperm sample was added to the same fertilisation droplets containing the oocytes.

that PKG I is absent in human sperm, and the effect of high concentration cGMP may be explained by a crossactivation of PKA (Willipinski-Stapelfeldt et al. 2004). However, H89, a PKA inhibitor, could not block cGMPinduced acrosome reaction in our study. The absence or presence of PKG I in pig sperm needs further study. It is also possible that other signal transduction pathways (such as cGMP-gated ion channels) might be involved in this process (Willipinski-Stapelfeldt et al. 2004). The optimal concentration of ANP for induction of the acrosome reaction in pig spermatozoa in the present study was consistent with dissociation constants obtained for ANP binding to human spermatozoa (Silvestroni et al. 1992) and also with concentrations in follicular fluids (Anderson et al. 1994), suggesting a physiological role for ANP in the regulation of the acrosome reaction.

Fresh pig sperm were used for the fertilisation experiments, as in the acrosome study. It has been reported that the treatment of spermatozoa with caffeine results in increased in vitro penetration rates of bovine (Niwa \& Ohgoda 1988) and porcine (Wang et al. 1991, Zhao et al. 2002) oocytes, and also results in a higher proportion of fertilisation (Parrish et al. 1986, Niwa \& Ohgoda 1988). However, the incidence of sperm penetration was either low or nil in mTBM medium without caffeine (Abeydeera \& Day 1997b, Zhao et al. 2002). ANP had a similar effect on the proportion of oocytes penetrated and fertilisation as that of caffeine, suggesting that ANP may play a physiological role in fertilisation. The effect of ANP on IVF might occur via the PKG pathway, since the parameters of ANP-induced fertilisation could be completely reversed by KT5823.

The acrosome reaction is absolutely required for fertilisation. Before sperm can penetrate the egg, they are subjected to physiological alteration (capacitation) in the female reproductive tract. Capacitation prepares the sperm cell for binding to the egg and exocytosis (acrosome reaction). It is becoming increasingly clear that the

Table 3 Development of pig oocytes inseminated with caffeine or ANP preincubated spermatozoa

\begin{tabular}{|c|c|c|c|c|}
\hline & No. oocytes & $\begin{array}{l}\text { Cleavage rate } \\
(\%)\end{array}$ & $\begin{array}{l}\text { Blastocyst rate } \\
(\%)\end{array}$ & $\begin{array}{l}\text { No. cells/ } \\
\text { blastocyst }^{\dagger}\end{array}$ \\
\hline \multicolumn{5}{|l|}{ Treatment } \\
\hline Control & 374 & $14 \cdot 8 \pm 5 \cdot 7$ & 0 & - \\
\hline Caffeine $e^{\ddagger}$ & 325 & $62 \cdot 7 \pm 4 \cdot 6$ & $25 \cdot 8 \pm 2 \cdot 6$ & $35 \cdot 6 \pm 1 \cdot 9$ \\
\hline ANP§ & 346 & $60 \cdot 2 \pm 5 \cdot 1$ & $26 \cdot 7 \pm 3 \cdot 2$ & $38 \cdot 4 \pm 2 \cdot 3$ \\
\hline KT5823 & 258 & $16 \cdot 4 \pm 5 \cdot 3$ & 0 & - \\
\hline ANP+KT5823 & 236 & $19 \cdot 7 \pm 4 \cdot 2$ & 0 & - \\
\hline
\end{tabular}




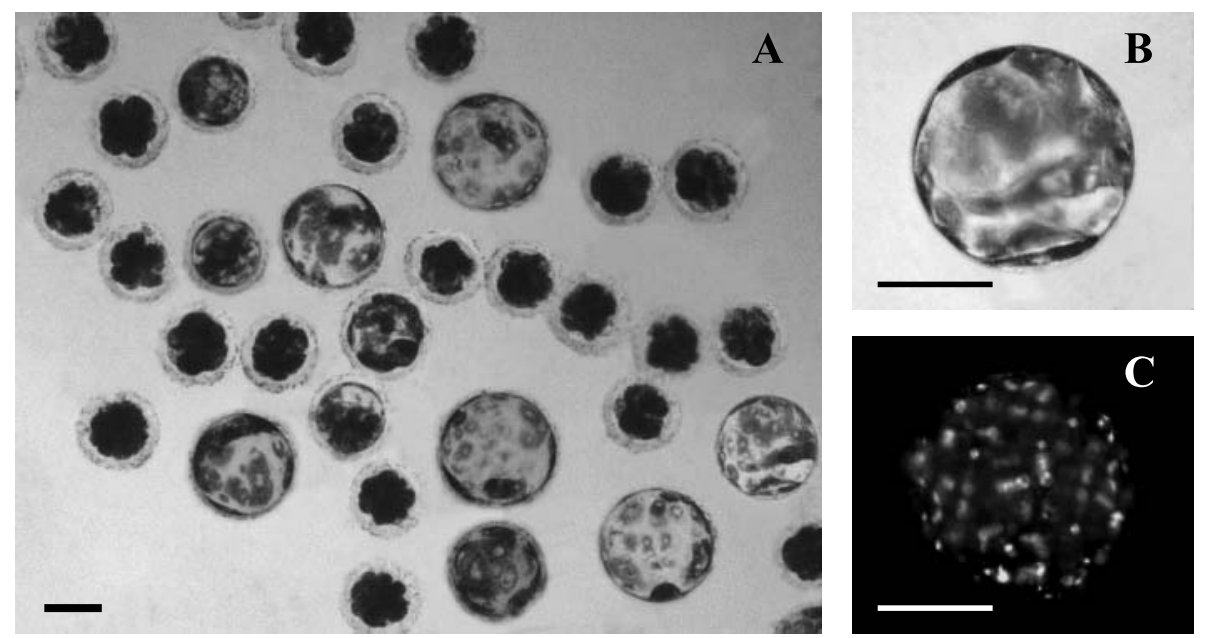

Figure 9 Image of blastocyst obtained from pig oocytes inseminated with ANP treated sperm. (A) Overall picture of blastocysts formed in a culture well 6 days after IVF. Note variation in morphology and size of apparent blastocysts. Bar $=100 \mu \mathrm{m}$. (B) Enlarged image of a blastocysts. Bar $=100 \mu \mathrm{m}$. (C) Fluorescent image of a blastocyst stained with Hoechst 33342. Bar=100 $\mu \mathrm{m}$.

acrosome reaction is normally restrained until oocyte ligands bind to sperm receptors. Caffeine has been known to enhance and prolong the motility of bull and boar spermatozoa (Garbers et al. 1971,1973) and accelerate the rate of capacitation by precociously increasing the concentration of cAMP (Fraser 1979), but had no effect on the acrosome reaction in our study. Sperm treated with caffeine may reach and bind to the ZP by hyperactivated motility, and then receive a signal that causes the acrosome react (Yanagimachi 1994). Recent evidence suggests that sperm may initiate the acrosome reaction during capacitation which could lead to exposure of acrosomal protein(s) (e.g., sp56) that permit binding to ZP3 and fertilisation (Wassarman et al. 2001, Primakoff \& Myles 2002). Although ANP had a similar effect on improving the fertilising ability of pig spermatozoa to that of caffeine, different mechanisms may exist during this process. In the present study, an ANP-induced acrosome reaction (not the capacitation) may have contributed to the higher proportion of oocytes that are penetrated and fertilized, in previous studies, chondroitin sulfate and heparin could facilitate bovine IVF by inducing the acrosome reaction (Lenz et al. 1983, Parrish et al. 1986). Although the majority of sperm that bind to the ZP are acrosome-intact regardless of the percentage of acrosome-reacted sperm in suspension (Fazeli et al. 1997), sperm attachment to the zona does not require capacitation and is not a functional indicator of zona penetration (Lynham \& Harrison 1998). On the other hand, ANP can induce attraction (chemotaxis) and enhance swimming speed (chemokinesis) in human spermatozoa in vitro (Zamir et al. 1993, Anderson et al. 1995), which might also be involved in this process.

It is reported that high-affinity NPRA (particulate guanylyl cyclase receptors) has been particularly localized in human spermatozoa (Silvestroni et al. 1992), and that ANP is synthesized in the mucosal layer of the oviduct in rat, and the concentration of oviductal ANP begins increase at the estrus and metestrus stage of estrous cycle (Kim et al. 1997). In our study, the high levels of ANP gene were expressed at OT3 stage (the large follicle stage), and the expression of NPRA gene was detected in pig spermatozoa. All these results suggest that the locally synthesized ANP may serve as a physiological agonist in the regulation of the acrosome reaction and fertilisation. Elucidation of the mechanism of ANP-induced acrosome reaction and the fertilising ability would provide further understanding of this fundamental biological process, and generate clinical advances for treatment of infertility. In addition, the prevention of spermatozoa acrosome reaction induced by ANP may become an exciting new approach to contraception.

In conclusion, the ANP mRNA and protein is expressed in the oviduct, but only NPRA gene is detected in pig spermatozoa. ANP induces acrosome reaction in preincubated spermatozoa, apparently via a PKG pathway. Furthermore, ANP also enhances the fertilising ability of spermatozoa. These results imply that ANP, which is locally produced in the oviduct, may serve as a physiological agonist in the regulation of fertilisation in the intact animal.

\section{Acknowledgements}

This research was supported by grants for National Outstanding Youth foundation of China (No. 30025032), National Natural Science Foundation of China (No. 30470868) and Beijing Natural Science Foundation (No. 
5052017). The authors declare that there is no conflict of interest that would prejudice the impartiality of this scientific work.

\section{References}

Abeydeera LR \& Day BN 1997a Fertilization and subsequent development in vitro of pig oocytes inseminated in modified tris-buffered medium with frozen-thawed ejaculated spermatozoa. Biology of Reproduction 57 729-734.

Abeydeera LR \& Day BN 1997 b In vitro penetration of pig oocytes in a modified Tris-buffered medium: effect of BSA, caffeine and calcium. Theriogenology 48 537-544.

Anderson RA, Feathergill KA, Drisdel RC, Rawlins RG, Mack SR \& Zaneveld LJ 1994 Atrial natriuretic peptide (ANP) as a stimulus of the human acrosome reaction and a component of ovarian follicular fluid: correlation of follicular ANP content with in vitro fertilization outcome. Journal of Andrology 15 61-70.

Anderson RA, Feathergill KA, Rawlins RG, Mack SR \& Zaneveld LJ 1995 Atrial natriuretic peptide: a chemoattractant of human spermatozoa by a guanylate cyclase-dependent pathway. Molecular Reproduction and Development 40 371-378.

Austin CR 1951 Observations on the penetration of the sperm into the mammalian egg. Austrian Journal Science Research B 4 581-596.

Baxter JD, Lewicki JA \& Gardner DG 1988 Atrial natriuretic peptide. Biotechnology 6 529-546.

Bovy PR, O’Neal JM, Olins GM \& Patton DR 1989 Identification of structural requirements for analogues of atrial natriuretic peptide (ANP) to discriminate between ANP receptor subtypes. Journal of Medicine and Chemistry 32:869-874.

Chang MC 1951 Fertilizing capacity of spermatozoa deposited into the fallopian tubes. Nature 168 697-698.

Drewett JG, Ziegler RJ \& Trachte GJ 1992 Neuromodulatory effects of atrial natriuretic peptides correlate with an inhibition of adenylate cyclase but not an activation of guanylate cyclase. Journal of Pharmacology Experiment and Therapeutics 260 689-696.

Evrard A, Hober C, Racadot A, Lefebvre J \& Vantyghem MC 1999 Atrial natriuretic hormone and endocrine functions. Annales de Bioloqie Clinique 57 149-155.

Fan HY, Tong C, Lian L, Li SW, Gao WX, Cheng Y, Chen DY, Schatten H \& Sun QY 2003 Characterization of ribosomal S6 protein kinase p90 rsk during meiotic maturation and fertilization in pig oocytes: mitogen-activated protein kinase-associated activation and localization. Biology of Reproduction 68 968-977.

Fazeli A, Hage WJ, Cheng FP, Voorhout WF, Marks A, Bevers MM \& Colenbrander B 1997 Acrosome-intact boar spermatozoa initiate binding to the homologous zona pellucida in vitro. Biology of Reproduction 56 430-438.

Flynn TG, de Bold ML \& de Bold AJ 1983 The amino acid sequence of an atrial peptide with potent diuretic and natriuretic properties. Biochemical and Biophysical Research Communications 117 859-863.

Fraser LR 1979 Accelerated mouse sperm penetration in vitro in the presence of caffeine. Journal of Reproduction and Fertility 57 377-384.

Funahashi H, Cantley TC \& Day BN 1994 Different hormonal requirement of pig oocyte-cumulus complexes during maturation in vitro. Journal of Reproduction and Fertility 101 159-165.

Garbers DL, First NL, Sullivan JJ \& Lardy HA 1971 Stimulation and maintenance of ejaculated bovine spermatozoa respiration and motility by caffeine. Biology of Reproduction 5 336-339.

Garbers DL, First NL, Gorman SK \& Lardy HA 1973 The effects of cyclic nucleotide phosphodiesterase inhibitors on ejaculated porcine spermatozoa metabolism. Biology of Reproduction 8 599-606.

Gutkowska J \& Nemer M 1989 Structure, expression, and function of atrial natriuretic factor in extraatrial tissues. Endocrinology Review 10 519-536.
Hunter RHF 1993 Sperm:egg ratios and putative molecular signals to modulate gamete interactions in polytocous mammals. Molecular Reproduction and Development 35 324-327.

Hunter RHF \& Polge C 1966 Maturation of follicular oocytes in the pig after injection of human chorionic gonadotropin. Journal of Reproduction and Fertility 12 525-531.

Ivanova MD, Gregoraszczuk EL, Augustowska K, Kolodziejczyk J, Mollova MV \& Kehayov IR 2003 Localization of atrial natriuretic peptide in pig granulosa cells isolated from ovarian follicles of various size. Reproductive Biology 3 173-181.

Johnson KM, Hughes FM Jr, Fong YY, Mathur RS, Williamson HO \& Gorospe WC 1994 Effects of atrial natriuretic peptide on rat ovarian granulosa cell steroidogenesis in vitro. American Journal of Reproductive Immunology 31 163-168.

Joyce C, Nuzzo N, Wilson L \& Zaneveld LJD 1987 Evidence for a role of cyclooxygenase (prostaglandin synthetase) and prostaglandins in the sperm acrosome reaction and fertilization. Journal of Andrology 8 74-82.

Kikuchi K, Onishi A, Kashiwazaki N, Iwamoto M, Noguchi J, Kaneko H, Akita T \& Nagai T 2002 Successful piglet production after transfer of blastocysts produced by a modified in vitro system. Biology of Reproduction 66 1033-1041.

Kim SH, Cho KW, Lim SH, Hwang YH, Ryu H, Oh SH, Seul KH, Jeong GB \& Yoon S 1992 Presence and release of immunoreactive atrial natriuretic peptide in granulosa cells of the pig ovarian follicle. Regulatory Peptide 42 153-162

Kim SH, Cho KW, Oh SH, Hwang YH, Lim SH, Ryu H, Seul KH, Jeong GB \& Yoon S 1993 Immunoreactive atrial natriuretic peptides in the oocyte. Comparative Biochemistry and Physiology: Comparative Physiology 104 219-223.

Kim SH, Cho KW, Kim SZ \& Koh GY 1997 Characterization of the atrial natriuretic peptide system in the oviduct. Endocrinology 138 2410-2416.

King GJ \& Macpherson JW 1973 A comparison of two methods for boar semen collection. Journal of Animal Science 36 563-565.

Lenz RW, Ball GD, Lohse JK, First NL \& Ax RL 1983 Chondroitin sulfate facilitates an acrosome reaction in bovine spermatozoa as evidenced by light microscopy, electron microscopy and in vitro fertilization. Biology of Reproduction 28 683-690.

Lynham JA \& Harrison RAP 1998 Use of stored pig eggs to assess boar sperm fertilizing functions in vitro. Biology of Reproduction 58 539-550.

Mägert HJ, Appelhans H, Gassen HG \& Forssmann WG 1990 Nucleotide sequence of a porcine prepro atrial natriuretic peptide (ANP) cDNA. Nucleic Acids Research 186704.

Niwa K \& Ohgoda O 1988 Synergistic effect of caffeine and heparin on in-vitro fertilization of cattle oocytes matured in culture. Theriogenology 30 733-741.

Ostermeier GC, Dix DJ, Miller D, Khatri P \& Krawetz SA 2002 Spermatozoal RNA profiles of normal fertile men Lancet $360772-777$.

Ostermeier GC, Miller D, Huntriss JD, Diamond MP \& Krawetz SA 2004 Delivering spermatozoan RNA to the oocyte Nature 429154.

Pandey KN, Nguyen HT, Li M \& Boyle JW 2000 Natriuretic peptide receptor-A negatively regulates mitogen-activated protein kinase and proliferation of mesangial cells: role of cGMPdependent protein kinase. Biochemical and Biophysical Research Communications 271 374-379.

Parrish JJ, Susko-Parrish JL \& First NL 1986 Effect of heparin and chondroitin sulfate on the acrosome reaction and fertility of bovine sperm in vitro. Theriogenology 24 537-549.

Parrish JJ, Susko-Parrish J, Winer MA \& First NL 1988 Capacitation of bovine sperm by heparin. Biology of Reproduction 38 1171-1180.

Parrish JJ, Krogenaes A \& Susko-Parrish JL 1995 Effect of bovine sperm separation by either swim up or Percoll method on success of in vitro fertilization and early embryonic development. Theriogenology 44 859-869. 
Pelletier G 1988 Radiographic localization of atrial natriuretic factor receptors in the rat testis. Journal of Andrology 9 352-355.

Petters RM \& Wells KD 1993 Culture of pig embryos. Journal of Reproduction and Fertility Supplement 48 61-73.

Piao FL, Park SH, Han JH, Cao C, Kim SZ \& Kim SH 2004 Dendroaspis natriuretic peptide and its functions in pig ovarian granulosa cells. Regulatory Peptides 118 193-198.

Primakoff P \& Myles DG 2002 Penetration, adhesion, and fusion in mammalian sperm-egg interaction. Science 296 2183-2185.

Roldan ER, Murase T \& Shi QY 1994 Exocytosis in spermatozoa in response to progesterone and zona pellucida. Science 266 1578-1581.

Rotem R, Paz GF, Homonnai ZT, Kalina M, Lax J, Breitbart H \& Naor Z $1992 \mathrm{Ca}^{2+}$-independent induction of acrosome reaction by protein kinase C in human sperm. Endocrinology 131 2235-2243.

Rotem R, Zamir N, Keynan N, Barkan D, Breitbart H \& Naor Z 1998 Atrial natriuretic peptide induces acrosomal exocytosis of human spermatozoa. American Journal of Physiology 274 E218-E223.

Ruskoaho H 1992 Atrial natriuretic peptide: Synthesis, release, and metabolism. Pharmacology Review 44 479-602.

Silvestroni L, Palleschi S, Guglielmi R \& Croce CT 1992 Identification and localization of atrial natriuretic factor receptors in human spermatozoa. Archaeological Andrology 28 75-82.

Smolenski A, Burkhardt AM, Eigenthaler M, Butt E, Gambaryan S, Lohmann SM \& Walter U 1998 Functional analysis of cGMPdependent protein kinases I and II as mediators of NO/cGMP effects. Naunyn-Schmiedeberg's Archives of Pharmacology 358 134-139.

Takei Y 2000 Structural and functional evolution of the natriuretic peptide system in vertebrates. International Review Cytology $1941-66$

Takei Y 2001 Does the natriuretic peptide system exist throughout the animal and plant kingdom. Comparative Biochemistry and Physiology Part B: Biochemistry and Molecular Biology 129 559-573.

Talbot P \& Chacon RS 1981 A triple stain technique for evaluating normal acrosome reaction of human sperm. Journal of Experimental Zoology 215 201-208.

Tornell J, Carlsson B \& Billig H 1990 Atrial natriuretic peptide inhibits spontaneous rat oocyte maturation. Endocrinology 126 1504-1508.

Vollmar AM, Mytzka C, Arendt RM \& Schulz R 1988 Atrial natriuretic peptide in bovine corpus luteum. Endocrinology 123 762-767.

Wang WH, Niwa K \& Okuda K 1991 In-vitro penetration of pig oocytes matured in culture by frozen-thawed ejaculated spermatozoa. Journal of Reproduction and Fertility 93 491-496.
Wassarman PM 1987 Early events in mammalian fertilization. Annual Review of Cell Biology 3 109-142.

Wassarman PM, Jovine L \& Litscher ES 2001 A profile of fertilization in mammals. Nature Cell Biology 3 E59-E64.

Willipinski-Stapelfeldt B, Lübberstedt J, Stelter S, Vogt K, Mukhopadhyay AK \& Müller 2004 Comparative analysis between cyclic GMP and cyclic AMP signalling in human sperm. Molecular Human Reproduction 10 543-552.

Wu GM, Sun QY, Mao J, Lai L, McCauley TC, Park KW, Prather RS, Didion BA \& Day BN 2002 High developmental competence of pig oocytes after meiotic inhibition with a specific M-phase promoting factor kinase inhibitor, butyrolactone I. Biology of Reproduction 67 170-177.

Yanagimachi R 1981 Mechanisms of fertilization in mammals. In Fertilization and Embryonic Development In Vitro, pp 81-182, Eds L Mastroianni and J Biggers. New York, NY, USA: Plenum Press.

Yanagimachi R 1994 Mammalian fertilization. In The physiology of Reproduction, pp 152-162, Eds E Knobil and JD Neil. New York, NY, USA: Raven Press.

Yanagimachi R \& Usui N 1974 Calcium dependence of the acrosome reaction and activation of guinea pig spermatozoa. Experimental Cell Research 89 161-174.

Yoshida M, Ishizaki Y \& Kawagishi H 1990 Blastocyst formation by pig embryos resulting from in-vitro fertilization of oocytes matured in vitro. Journal of Reproduction and Fertility 88 1-8.

Zamir N, Riven-Kreitman R, Manor M, Makler A, Blumberg S, Ralt D \& Eisenbach M 1993 Atrial natriuretic peptide attracts human spermatozoa in vitro. Biochemical and Biophysical Research Communications 197 116-122.

Zamir N, Barkan D, Keynan N, Naor Z \& Breitbart H 1995 Atrial natriuretic peptide induces an acrosomal exocytosis in bovine spermatozoa. American Journal of Physiology 269 E216-E221.

Zhao XM, Song XX, Kawai Y \& Niwa K 2002 Penetration in vitro of zona-free pig oocytes by homologous and heterologous spermatozoa. Theriogenology 58 995-1006.

Received in final form 13 January 2006

Accepted 25 January 2006

Made available online as an Accepted Preprint 15 February 2006 